permits is now essential in most, if not all, areas of the continent. It still is OK to listen and watch in most as long as it does not involve trespassing on private property without permission, but disturbing of animals or habitats is increasingly discouraged. The concluding sections cover the making of the book, acknowledgments, and credits for the photographs, the sound recordings, compact disc track description (mentioned earlier), sources and a sparse list for further reading (five field guides, four reference works, one on keeping frogs and toads as pets, six nonprofit and governmental websites, three volunteer monitoring programs (including Frogwatch Canada), regional websites, and three audio guides. Finally, a five-page index to species and groups concludes the book.

As a visual and auditory introduction to frogs, toads and their kin in North America, this book is outstanding. It would be a useful and relatively inexpensive addition to any reference shelf, a conversation starter on any coffee tables and a treasured gift for any natureappreciative and inquisitive relative or friend.

FRANCIS R. COOK

Research Associate and Curator Emeritus, Canadian Museum of Nature, P.O. Box 3443, Station D, Ottawa, Ontario K1P 6P4 Canada

\title{
Shorebirds of the Northern Hemisphere
}

By R. Chandler. 2009. Andrew Isles. Natural History Books, 115 Greville Street Prahran 3181 Australia. 448 pages, 90 AUD Paper.

\section{Shorebirds of North America, Europe and Asia}

By R. Chandler. 2009. Princeton University Press, 41 William Street, Princeton, New Jersey. 448 pages, 35 USD Paper.

I believe these two books are the same although there are differences in the press releases (850 vs. 700 photos, 134 vs. 135 species covered) provided by the two publishers. I think one is the European version and the one I have from Princeton is the North American. [Do not confuse this book with the 2006 Shorebirds of North America, Europe, and Asia: A Guide to Field Identification, by Stephen Message and Don Taylor and also published by Princeton.]

That being said, this book has the wow factor. At your first flick through you will see a mass of wonderful photos. After I had finished my initial ogle, I settled into a more systematic review.

The book starts with a section on plumage that is far more detailed than the typical introduction. It is also illustrated with examples of the feather developments. This is followed by a similarly-styled discussion of shorebird behaviour.

The species accounts cover jacanas, Painted Snipe and Crab Plover, oystercatchers, Ibisbill, avocets and stilts, thick-knees, Egyptian Plover and coursers, pratincoles, ringed plovers, small plovers, Pluvialis plovers, lapwings, sandpipers, snipe, dowitchers, woodcocks, godwits, curlews, Tring $a$ sandpipers, turnstones and phalaropes. This is a little different order than normal, but this does not detract from its use as a reference book. Each species has a thorough explanation of all plumages: juvenile, adult (breeding and non-breeding) and any racial variations. There is a description of status, habitat and a range map of summer, winter and permanent distribution.

Each account has several quarter to half page photos showing the various plumages described. There are some full-page photos too. All of the photos are lovely, crystal clear portraits of birds in habitat or feather details, including definitive flight shots. Most of them are by the author with additions from many other sources. These photos show more detail than can usually be seen in the field. For example, the Wilson's Snipe uses two tail feathers in its display as compared to the nearly-identical Common Snipe which uses one. This diagnostic feature is difficult to see on a swooping bird. I might try photographing the next displaying snipe I see, just to discover if I can pick out these feathers. [In 12 pages of Internet pictures there was only one flying Wilson's Snipe and its tail was closed]. You can see the variations in the various snipe superciliums very easily, unlike in the field.

Despite the use of North American term Shorebirds in the titles rather than the European Waders, the author uses European names throughout. Where there is an alternative name [Grey vs Black-bellied Plover] this is noted. Species splits are current [all the "golden" plovers for example. I did not have any issues with the range maps and distributions. Personally I have found the Yellow-wattled Lapwing rather hard to find and not "fairly common," but that is not valid basis for comment. Not included in the species accounts are Eskimo Curlew and Black-fronted Plover, as there are no current reliable records for the region covered.

Personally, I think this is a "must have" book for the serious observer. While many shorebirds are showy and easy to identify [avocets] others are a perpetual challenge. I wonder how many Little Stints have been overlooked in North America? Or Eurasian Oystercatchers? This book will provide a very handy reference and, one I am sure, I will be using frequently from now on.

ROY JOHN

2193 Emard Crescent, Ottawa, Ontario K1J 6K5 Canada 